\title{
Reverse Transcription Process
}

National Cancer Institute

\section{Source}

National Cancer Institute. Reverse Transcription Process. NCI Thesaurus. Code C17097.

The action of copying RNA into DNA by reverse transcriptase. 